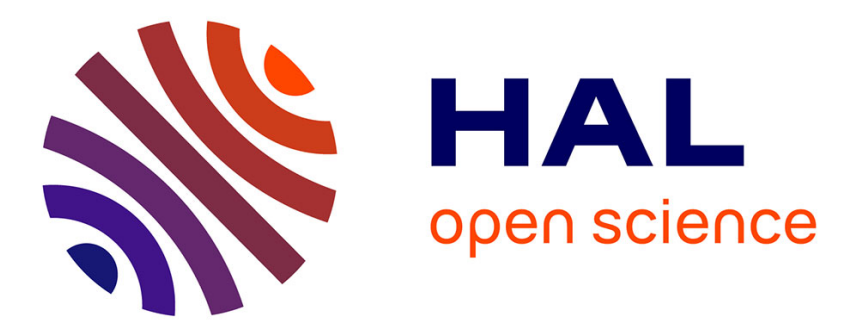

\title{
Effect of Sea Breeze on Air Pollution in the Greater Athens Area. Part II: Analysis of Different Emission Scenarios
}

\author{
Paola Grossi, Philippe Thunis, Alberto Martilli, Alain Clappier
}

\section{To cite this version:}

Paola Grossi, Philippe Thunis, Alberto Martilli, Alain Clappier. Effect of Sea Breeze on Air Pollution in the Greater Athens Area. Part II: Analysis of Different Emission Scenarios. Journal of Applied Meteorology, 2000, 39, pp.563-574. 10.1175/1520-0450(2000)0392.0.CO;2 . hal-03263077

\section{HAL Id: hal-03263077 https://hal.science/hal-03263077}

Submitted on 16 Jun 2021

HAL is a multi-disciplinary open access archive for the deposit and dissemination of scientific research documents, whether they are published or not. The documents may come from teaching and research institutions in France or abroad, or from public or private research centers.
L'archive ouverte pluridisciplinaire HAL, est destinée au dépôt et à la diffusion de documents scientifiques de niveau recherche, publiés ou non, émanant des établissements d'enseignement et de recherche français ou étrangers, des laboratoires publics ou privés. 


\title{
Effect of Sea Breeze on Air Pollution in the Greater Athens Area. Part II: Analysis of Different Emission Scenarios
}

\author{
Paola Grossi and Philippe Thunis \\ Joint Research Centre, Environment Institute, Ispra, Italy \\ Alberto Martilli and Alain Clappier \\ École Polytechnique Fédérale de Lausanne, Laboratoire de la Pollution Atmosphérique et Sol, \\ Lausanne, Switzerland
}

(Manuscript received 9 March 1998, in final form 26 March 1999)

\begin{abstract}
The Mediterranean Campaign of Photochemical Tracers-Transport and Chemical Evolution that took place in the greater Athens area from 20 August to 20 September 1994 has confirmed the role of sea-breeze circulation in photochemical smog episodes that had been suggested already by a number of experiments and numerical studies.

The meteorological and photochemical modeling of this campaign were discussed in Part I. Part II focuses on the study of the 14 September photochemical smog event associated with a sea-breeze circulation. The objective of the study is to identify and to understand better the nonlinear processes that produce high ozone concentrations. In particular, the effect of land and sea breezes is investigated by isolating the effect of nighttime and daytime emissions on ozone concentrations. The same principle then is used to isolate the effect on ozone concentrations of the two main sources of emissions in the greater Athens area: the industrial area around Elefsis and the Athens urban area. Last, the buildup of ozone from one day to another is investigated.

From this study, it comes out that ozone production in the Athens area is mainly a 1-day phenomenon. The increased values of photochemical pollutant (up to $130 \mathrm{ppb}$ at ground level) reached during summertime late afternoons on mountain slopes to the north and northeast of the city are related mainly to the current-day emissions. Nevertheless, the recirculation of old pollutants can have an important effect on ozone concentrations in downtown Athens, the southern part of the peninsula, and over the sea, especially near Aigina Island.
\end{abstract}

\section{Introduction}

In recent decades, the Athens basin has suffered from severe air pollution problems. Athenian smog is composed primarily of photochemical oxidants, that is, chemical substances formed in the atmosphere under the influence of solar radiation when nitrogen oxides $\left(\mathrm{NO}_{\mathrm{x}}\right)$ and hydrocarbons are present (Moussiopoulos et al. 1995).

Two main sources of primary pollutants responsible for these bad air quality conditions can be identified in the greater Athens area (GAA). The first is road traffic in the city of Athens, which is responsible for all carbon monoxide (CO), three-fourths of the $\mathrm{NO}_{\mathrm{x}}$, and nearly two-thirds of the volatile organic compound (VOC) emissions. The second source consists of the industrial area around Elefsis on the Thriasson Plain coast (Fig. 1).

Corresponding author address: Paola Grossi, TP 321, JRC, 21020 Ispra (VA), Italy.

E-mail: Paola.Grossi@jrc.it
As pointed out by a number of experiments (e.g., Gusten et al. 1988) and numerical studies (e.g., Kallos et al. 1991), photochemical smog episodes in Athens generally are associated with specific meteorological conditions such as weak synoptic forcing and sea-breeze circulations. Several modeling exercises, carried out in the framework of the Athenian Photochemical Smog Intercomparison of Simulations project, have indicated some dynamical mechanisms that contribute to the formation of pollution during the sea-breeze regime. The increased pollution along the coast during the earlymorning hours is related to the recirculation of pollutants advected over the sea during night hours (Nester 1995). The highest ozone $\left(\mathrm{O}_{3}\right)$ concentrations during photochemical smog episodes are found in the late afternoon in the suburban area to the east-northeast of Athens. This ozone is produced downtown during the morning hours because of the large emissions of nitrogen oxides and hydrocarbons and then is transported north-northeast by the sea breeze (Pilinis et al. 1993).

A confirmation of the sea breeze's role in photochemical smog episodes was found experimentally dur- 


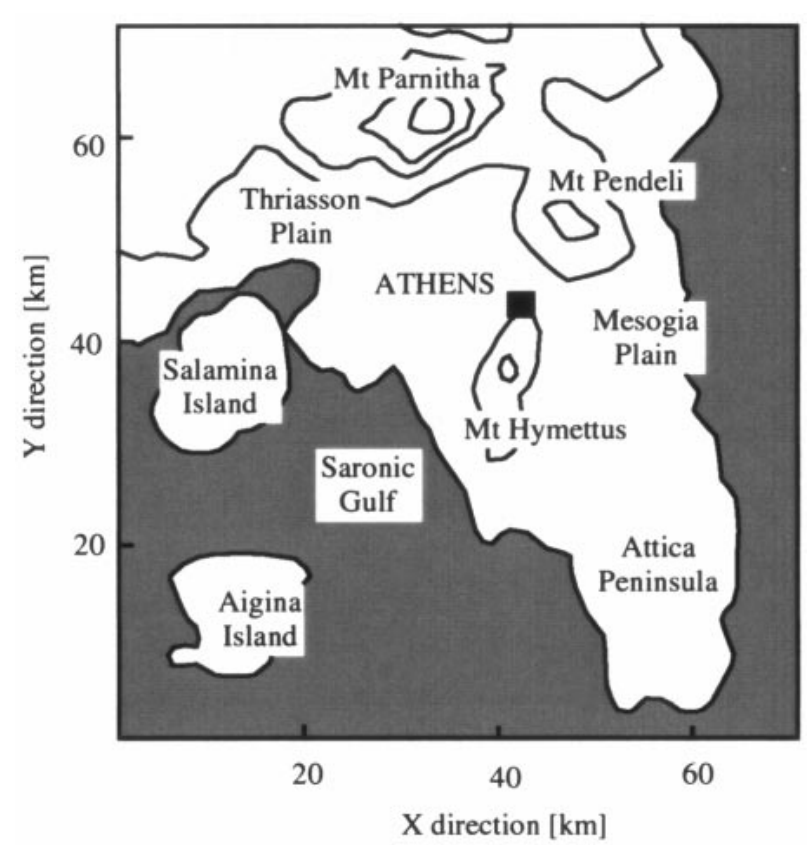

FIG. 1. The greater Athens area: model computational domain and topography (contour lines every $200 \mathrm{~m}$ ). The square indicates Demokritos station.

ing the Mediterranean Campaign of Photochemical Tracers-Transport and Chemical Evolution (MEDCAPHOT-TRACE). The experiment took place in GAA from 20 August to 20 September 1994. The meteorological and photochemical modeling of MEDCAPHOT-TRACE was discussed in Part I (Clappier et al. 2000) in which results from the Topographic Vorticity-Mode (TVM) model using the Lurmann-CarterCoyner (LCC) chemical mechanism are evaluated quantitatively by comparison with a large number of meteorological and chemical measurements collected during the campaign. The comparison between field measurements and model results has shown that the dynamical photochemical TVM-LCC model was able to reproduce the main characteristics of the circulation and the photochemical pollution formation in the Athens basin. The numerical model therefore can be used now as a tool to understand and to quantify the different physical and chemical mechanisms responsible for photochemical smog formation.

This second part of the paper focuses on the study of the 14 September circulation. Results from Part I showed that this day represents a typical case of summertime sea-breeze regime associated with a photochemical smog episode. The goal of this study is to identify and to understand better the nonlinear processes that give rise to high ozone concentrations. The temporal variability and the spatial distribution of the emission sources are two factors that directly influence ozone formation. The first of these two factors is analyzed by isolating the contributions from nighttime and daytime emissions. In particular, the role of sea and land breezes is investigated in relation to the related emissions. To study the role of sources' spatial distribution, two major emission areas within GAA are identified: the urbanized Athens area (Athens basin) and the industrial Elefsis area in the Thriasson Plain (Elefsis basin). An analysis is carried out to isolate and to quantify the contributions of each basin's emissions to the ozone concentrations within GAA. Finally, the buildup of ozone from one day to another is investigated in relation to sea-breeze recirculation and its impact is quantified.

In addition to the general objective of a better understanding of physical and chemical processes, this information should be relevant for future campaign planning and to support decision making on abatement strategy.

\section{Model description and initialization}

The model used in this study is TVM-LCC, which is composed of the mesoscale meteorological TVM code (Thunis 1995; Schayes et al. 1996; Bornstein et al. 1996) and the California Institute of Technology photochemical model (McRae et al. 1982) with the LCC chemical mechanism. TVM is a finite-difference, nonhydrostatic, and incompressible vorticity-mode mesoscale model written in a terrain-following coordinate system.

The gas-phase chemical system is the condensed LCC mechanism (Lurmann et al. 1987) expanded by Harley et al. (1993) to treat biogenic emissions and fuel additives explicitly. It considers 44 species coupled via 106 reactions.

The modeling domain (Fig. 1) is $72 \mathrm{~km} \times 72 \mathrm{~km}$ with a grid box area of $2 \mathrm{~km} \times 2 \mathrm{~km}$. For the meteorological modeling, eight additional grid points are added horizontally at the lateral boundaries, and 24 levels are used in the vertical: the lowest level is fixed at 30 $\mathrm{m}$ above ground level (AGL), and the model top is 8600 $\mathrm{m}$. The photochemical module runs with 11 levels in the vertical up to $3250 \mathrm{~m}$ AGL.

The dynamical simulation starts on 13 September at 2200 LT (local time; UTC $+3 \mathrm{~h}$ ) and continues until midnight the following day. The initialization is performed on the basis of soundings taken at Hellinikon Airport. The transport/chemical simulations start at 0000 LT. Results from the previous day (13 September) are used as initial conditions for the current run.

The emissions inventory (which is the same as in Part I) comes from the Athens 2004 database built on reference data for 1990. Additional updated information about the traffic volume and the spatial distribution of the industrial emissions sources was included. The hourly emission rates were calculated for $\mathrm{NO}_{\mathrm{x}}$, sulfur dioxide $\left(\mathrm{SO}_{2}\right)$, and VOC, assuming constant annual emission rates. For more details about the model description and its application, the reader is referred to Part I (Clappier et al. 2000). 


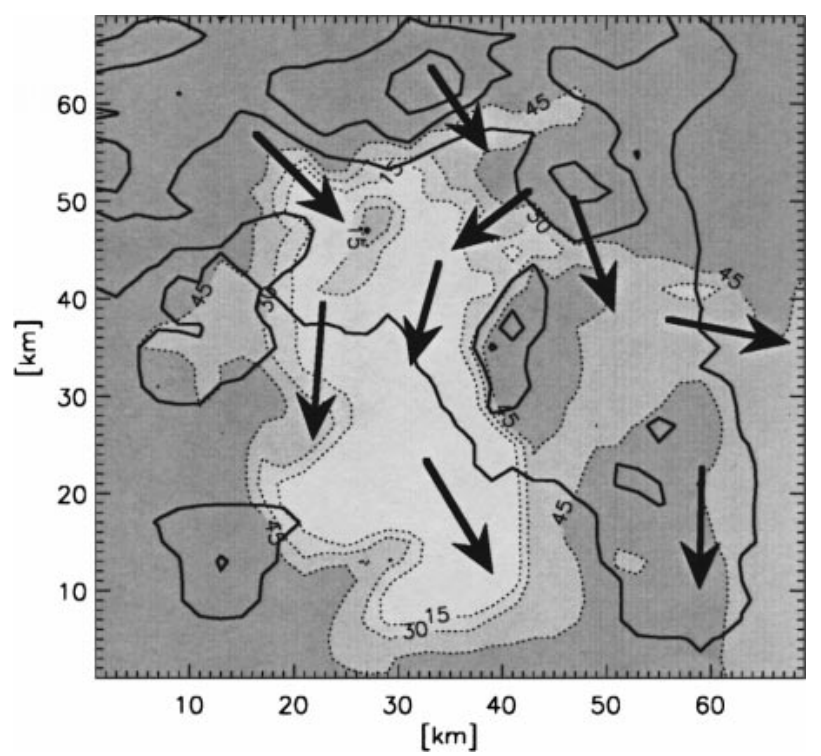

FIG. 2. Modeled distribution of the 15-m ozone at 0400 LT (contour lines every $15 \mathrm{ppb}$ ). Arrows indicate the prevailing near-surface wind directions.

\section{Description of the 14 September pollution event}

In Part I, a validation of both the meteorological and photochemical simulations has been given by comparing the various ground-station measurements with the model results. The TVM-LCC model was shown to reproduce well the observations during the period from 12 to 14 September 1994. During 12 and 13 September, a strong synoptic wind from the north (Etesian winds) prevented the development of sea breezes, and low ozone concentrations were calculated over GAA (usually around $60 \mathrm{ppb}$ ) in agreement with measurements. On the contrary, on 14 and 15 September the synoptic forcing was weak. During the sea-breeze development, high ozone concentrations ( $150 \mathrm{ppb})$ were calculated and measured north and east of the city.

In the following sections, only the meteorological and chemical modeling results for the 14 September photochemical smog event are presented and discussed (for more details see Part I).

\section{a. Nighttime and early morning}

During the night, downslope winds form on Parnitha, Pendeli, and the Hymettus Mountains to reach a maximum intensity of about $8 \mathrm{~m} \mathrm{~s}^{-1}$ and merge with the land breeze near the coast, forming relatively strong offshore winds $\left(4 \mathrm{~m} \mathrm{~s}^{-1}\right)$ within the Athens basin. Along the western coast of the peninsula, the flow is directed mostly toward the south, along the shoreline (see Part I, Fig. 13a). Prevailing wind directions are sketched on the ozone contour map in Fig. 2.

The following three regions related to ozone pollution can be identified: 1) the border that consists of the areas

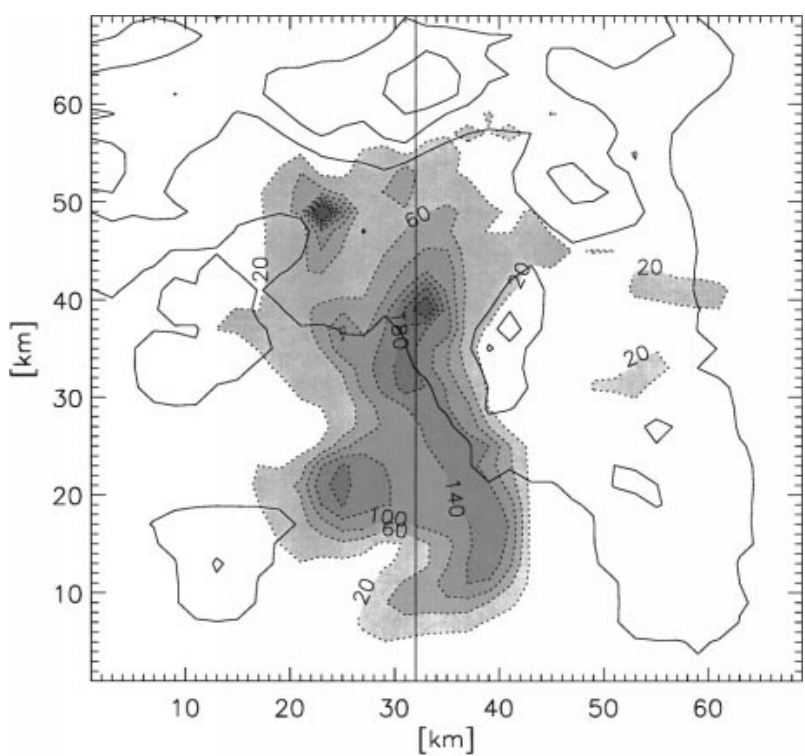

FIG. 3. Map of the 15-m modeled $\mathrm{NO}+\mathrm{NO}_{2}$ distribution at 0400 LT (contour lines every $40 \mathrm{ppb}$ ). The line gives the location of the vertical cross section presented in Fig. 4.

north and east of the mountain ridges, 2) the Athens urban center, and 3) the sea. During nighttime, a constant background ozone inflow is observed (Fig. 2) in the northeast part of the domain. Over Athens city, the high urban $\mathrm{NO}_{\mathrm{x}}$ emissions, maintained in a very shallow and thermally stable layer, destroy ozone. The general offshore winds discussed previously push this pollution (Athens emissions) over the sea. The ozone contour map at $15 \mathrm{~m}$ above surface (Fig. 2) shows a cloud of low ozone values over the city that extends to the coastline and to the southeast. The surface distribution of nitric oxide plus nitrogen dioxide ( $\mathrm{NO}+\mathrm{NO}_{2}$; Fig. 3), shows a cloud of elevated $\mathrm{NO}_{x}$ concentration that corresponds well to the area of lower ozone concentration. The NO levels reach their maximum value over the Athens urban center, and $\mathrm{NO}_{2}$ levels are localized, mainly along the coastline (not shown). This pattern can be attributed to the fact that $\mathrm{NO}$ principally is emitted, and $\mathrm{NO}_{2}$ increases via the nighttime destruction of $\mathrm{O}_{3}$ through the reaction $\mathrm{NO}+\mathrm{O}_{3} \rightarrow \mathrm{NO}_{2}+\mathrm{O}_{2}$, where $\mathrm{O}_{2}$ is molecular oxygen, and from the contribution of other nitrogen oxides such as $\mathrm{NO}_{3}$ and $\mathrm{N}_{2} \mathrm{O}_{5}$. In Fig. 4, the vertical cross section of $\mathrm{NO}+\mathrm{NO}_{2}$ passing through Athens shows that, at $0400 \mathrm{LT}$, pollutants are trapped over the sea and over the land in a shallow (stable) layer of about 150$200 \mathrm{~m}$.

\section{b. Daytime}

At sunrise, pollutants trapped over the sea within a very shallow layer start to react, forming ozone. During the morning hours (from 0900 to $1000 \mathrm{LT}$ ), the wind progressively turns to be directed onshore finally at around 1100 LT. At 1600 LT, sea breezes are developed 


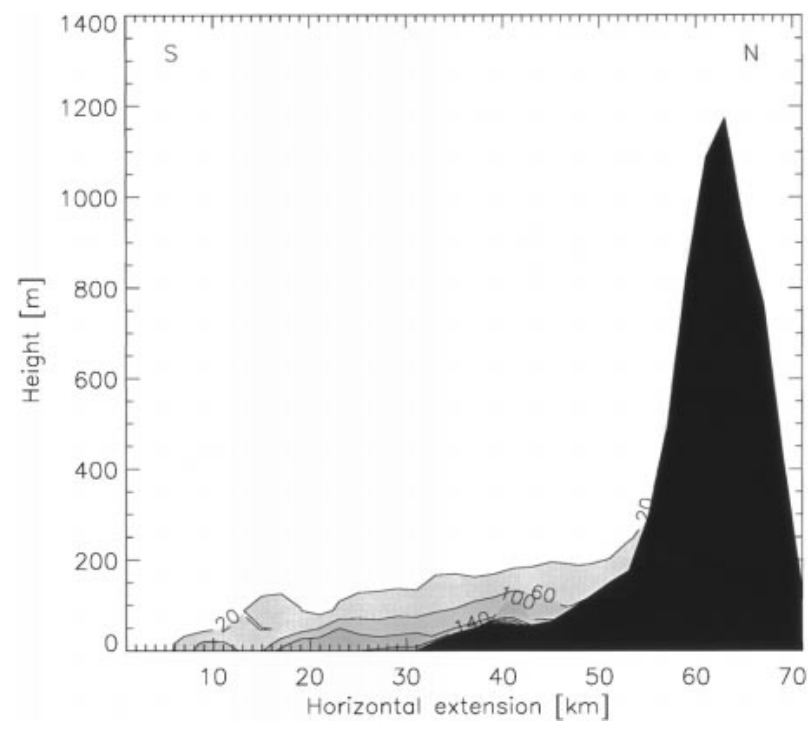

FIG. 4. Vertical north-south cross section of the modeled NO + $\mathrm{NO}_{2}$ distribution at $0400 \mathrm{LT}$ (contour lines every $40 \mathrm{ppb}$ ).

fully (as seen in Fig. 5, in which main wind directions are represented schematically). According to Kallos et al. (1991), three main sea-breeze systems can be identified for GAA. One is from the Saronic Gulf toward Athens, where near-surface winds blow from southwest to northeast (about $225^{\circ}$ ). A second cell develops over the Thriasson Plain, within the Elefsis basin, directed from west to east (about $260^{\circ}$ ). A third cell forms on the eastern side of the peninsula and is characterized by low-level winds from the east penetrating into the Mesogia Plain, east of Hymettus. The first two breeze cells, which blow in two neighboring basins separated only by a relatively low (less than $500 \mathrm{~m}$ ) hill barrier, merge at the foothill of the Parnitha Mountain about $20 \mathrm{~km}$ inland. The third sea breeze develops more slowly than do the other cells. In the early afternoon, however, the breeze is strong enough to penetrate into the valley between Pendeli and Hymettus. This penetration is confirmed by observations taken at Demokritos that show a sudden change in wind direction from $280^{\circ}$ to $90^{\circ}$ at 1600 LT.

The ozone map at 1600 LT (Fig. 5) shows low concentration areas over Athens and Elefsis due to high $\mathrm{NO}_{\mathrm{x}}$ emissions, which lead to a limited production of ozone (VOC-limited regime). The highest ozone concentrations are located along the mountain slopes on the western side of the Attica Peninsula, and the line of maximum concentration corresponds to the convergence line of the eastern and western sea-breeze fronts. In particular, at the Parnitha Mountain foothill where breezes from the Elefsis and Athens basins converge, high ozone concentrations are found late in the afternoon (160 ppb at $1800 \mathrm{LT}$ ). These concentrations probably correspond to the ozone generated over the sea and urban areas during the early morning hours. The high

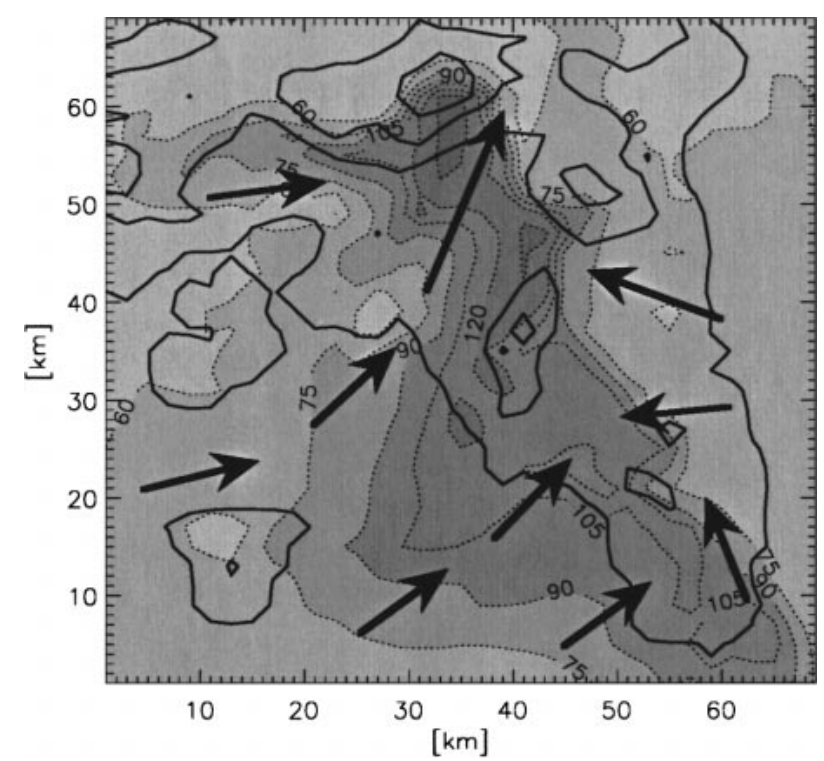

FIG. 5. Modeled distribution of the 15-m ozone at 1600 LT (contour lines every $15 \mathrm{ppb}$ ). Arrows indicate the prevailing near-surface wind directions.

ozone concentrations calculated over the sea correspond to the transformation of pollutant emitted during the night and trapped in the stable layer above the water surface.

Interesting is the case of Demokritos, which lies on the convergence front of the west and east sea breezes. During the early-afternoon hours, ozone concentrations remain more or less at background values until the Athens breeze reaches the station, carrying ozone concentrations as high as $150 \mathrm{ppb}$. This peak has a relatively short time duration $(1 \mathrm{~h})$, as wind direction shifts to easterly because of the prevailing eastern sea breeze. As a consequence, ozone concentrations return to the background value because this sea breeze carries "clean" air (60 ppb of ozone).

\section{Factor separation: Quantifying the interactions between atmospheric circulation and emissions during a photochemical smog episode}

From the previous description of the various seabreeze systems that develop over the Athens area, it is worthwhile to differentiate the role of different processes leading to high ozone concentrations. Three particular processes will be investigated: 1) the role of daytime versus nighttime emissions, 2) the buildup of pollution from one day to another, and 3) the role of Athens versus Elefsis basin emissions.

\section{a. Description of the method}

Evaluation of the effect of one factor on a given model result may be obtained straightforwardly by analyzing the difference between two simulations: one with and 
the other without the involved factor. On the other hand, the simultaneous evaluation of the effect of two (or more) factors is not so easy because of the nonlinearity of the involved processes. To isolate the effect of these linked processes, the factor separation method of Stein and Alpert (1993) will be used. In the above reference, the authors applied this technique to investigate the relative effect of topography and surface fluxes on rainfall distribution during a typical cyclone evolution in the Mediterranean. They showed that this technique is particularly well suited to isolate contributions from processes that are linked in a nonlinear way.

In summary, this method allows the identification of the contribution of one or more parameters in a global result. For example, to evaluate the contribution of factor $A$ and $B$, a series of four simulations is required. Let us denote by $S_{\text {tot }}, S_{A}, S_{B}$, and $S_{0}$ the simulations including both factors, factor $A$ only, factor $B$ only, and none of the factors, respectively. The effect (denoted by a hat) of factor $A$ and $B$ then is given, respectively, by

$$
\begin{aligned}
& \hat{S}_{A}=S_{A}-S_{0}, \quad \text { and } \\
& \hat{S}_{B}=S_{B}-S_{0} .
\end{aligned}
$$

The run including both factors is expressed as

$$
S_{\text {tot }}=S_{0}+\hat{S}_{A}+\hat{S}_{B}+\hat{S}_{A B},
$$

and the effect of the mutual interaction between the two factors is given by

$$
\begin{aligned}
\hat{S}_{A B} & =S_{\mathrm{tot}}-\hat{S}_{A}-\hat{S}_{B}-S_{0} \\
& =S_{\mathrm{tot}}-\left(S_{A}-S_{0}\right)-\left(S_{B}-S_{0}\right)-S_{0} \\
& =S_{\mathrm{tot}}-S_{A}-S_{B}+S_{0} .
\end{aligned}
$$

Note that $\hat{S}_{A B}$ represents the contribution due to the pure double interaction between $A$ and $B$. In general, the simultaneous evaluation of $n$ factors requires $2^{n}$ simulations for the separation of their individual contributions and of their possible interactions.

In the following sections, the effect of different emission scenarios on ozone concentrations is studied. In section $4 \mathrm{~b}$, the roles of daytime and nighttime emissions are investigated. Four 24-h simulations are considered for 14 September, with different emission scenarios: $S_{\text {tot }}$ including the complete emission inventory; $S_{N}$ and $S_{D}$ including, respectively, nighttime and daytime emissions only; and $S_{0}$ with no emissions.

In section $4 \mathrm{c}$, the role of pollutant recirculation is considered. For this purpose, each simulation of the previous section $\left(S_{\text {tot }}, S_{D}, S_{N}\right.$, and $\left.S_{0}\right)$ is used to initialize another 24-h simulation in which the meteorological conditions of 14 September and the full emission inventory are used. In this way, four scenarios are obtained that only differ by their initialization: $S_{\text {tot }}^{\prime}, S_{D}^{\prime}$, $S_{N}^{\prime}$, and $S_{0}^{\prime}$.

The role of the spatial distribution of emission sources is addressed in section 4d. Two main pollutant sources can be identified for GAA: the Athens road traffic and
TABLE 1. Summary of the simulation conditions for the different scenarios considered in section $4 \mathrm{~b}$. All the simulations are initialized with the results of a 24-h simulation of 13 Sep that uses the full emission inventory.

\begin{tabular}{ll}
\hline & Emissions during the 24-h simulation period (14 Sep) \\
\hline$S_{\text {tot }}$ & Total \\
$S_{D}$ & Daytime only \\
$S_{N}$ & Nighttime only \\
$S_{0}$ & None \\
\hline
\end{tabular}

the industrial area around Elefsis in the Thriasson Plain. The relative importance of these two sources is studied by analyzing again four 24-h simulations with the following emissions: $s_{\text {tot }}$, including both Athens and Elefsis emissions; $s_{A}$ and $s_{E}$ including, respectively, Athens and Elefsis emissions only; and $s_{0}$ without Athens and Elefsis emissions. For more details refer to Tables 1, 3, and 4.

Surface ozone maps for the control simulations $\left(S_{\text {tot }}\right.$, $S_{\text {tot }}^{\prime}$, and $s_{\text {tot }}$ ) are constructed by assigning to each grid cell the maximum ozone value reached during a 24-h cycle (note that maps therefore are not representative of a specific time). For all other scenarios $\left(S_{D}, S_{N}\right.$, etc.), ozone maps are built by taking, for each grid cell, ozone values at the time at which the ozone maximum is recorded in the specific control simulation.

\section{b. Roles of daytime and nighttime emissions}

In this section, a series of simulations is carried out to investigate independently the roles of nighttime and daytime emissions on ozone concentrations over Athens. Nighttime and daytime are defined by looking at the local meteorological behavior: daytime begins at 1000 LT, when the sea breeze starts to develop, and ends at $2200 \mathrm{LT}$, when the nocturnal circulation is installed. Daytime emissions contribute $60 \%$ of the total $(24 \mathrm{~h}$ ) $\mathrm{NO}_{\mathrm{x}}$ and VOC emissions.

The impact of 14 September nighttime and daytime emissions is studied in this section through a series of four 24-h simulations that differ by their emissions, as summarized in Table 1.

All the simulations are initialized by using the results of 13 September. Because of the strong synoptic forcing from the north on that day, all emissions were transported toward the south of the domain. Consequently, the simulation of 14 September starts with no significant initial pollutant concentrations at high and ground levels.

The control simulation obtained by including both daytime and nighttime emissions $\left(S_{\text {tot }}\right)$ is shown in Fig. 6 . The map represents the maximum surface concentrations reached over the $24-\mathrm{h}$ cycle at each grid point. As described before, maximum concentrations are simulated along the convergence line of the different seabreeze systems with peaks on the mountain slopes of Parnitha, Pendeli, and Hymettus, whereas values of about 90-100 ppb characterize the Athens basin region. 


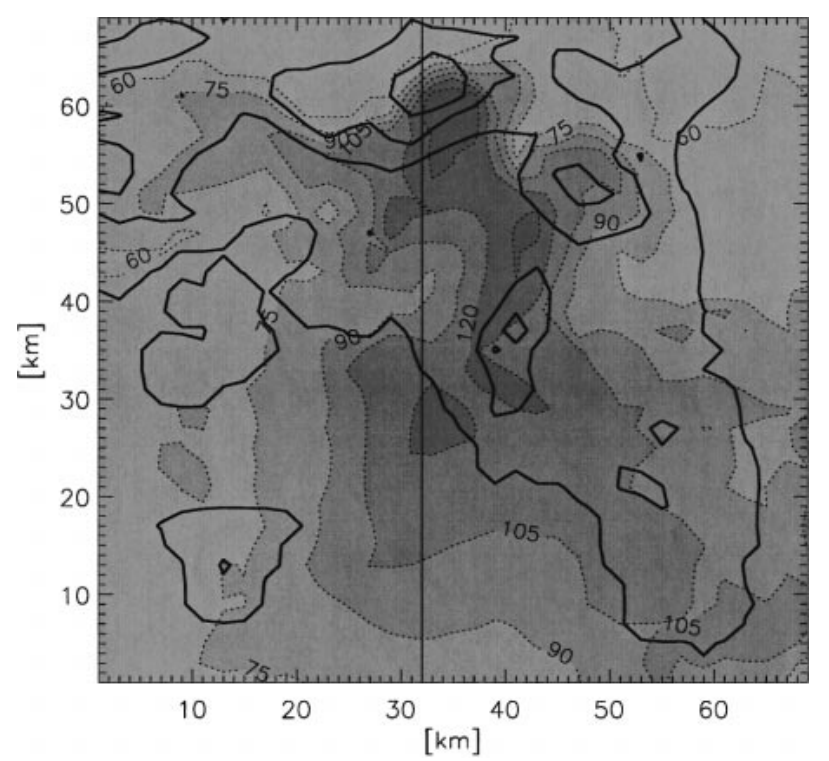

FIG. 6. Map of the 15-m maximum ozone concentrations reached over a $24-\mathrm{h}$ cycle in the control simulation $\left(S_{\text {tot }}\right)$. Contour lines are plotted every $15 \mathrm{ppb}$. The line gives the location of the vertical cross section presented in Figs. 8a-d.

The effect of daytime emissions only $\left(\hat{S}_{D}=S_{D}-S_{0}\right)$ is illustrated in Fig. 7a. It shows that the largest effect on ozone concentrations is located in the sea-breeze convergence region, with a maximum of about 50-60 $\mathrm{ppb}$ at the foothill of Parnitha Mountain, where the Elefsis and Athens basin breezes converge. All positive effects (ozone creation) of daytime emissions are found inland, while over the region of Athens, almost no effect is seen. This result implies that abatement strategies based on a reduction of daytime emissions would not affect the general ozone concentration level in the city center, but would affect only the northern neighboring regions. Note that this implication is true for the specific day considered here and for $\mathrm{NO}_{\mathrm{x}}$ and VOC emissions reduced in identical proportions.

In Fig. $7 \mathrm{~b}$, the effect of night emissions only $\left(\hat{S}_{N}=\right.$ $S_{N}-S_{0}$ ) is more diffused and extends over a large part of the Athens basin. The maximum effect still is seen on the mountainsides such as Parnitha or Hymettus and has the same order of magnitude as for the $\hat{S}_{D}$ case $(60$ $\mathrm{ppb})$. Over the city of Athens, the effect of night emissions (about $40 \mathrm{ppb}$ ) is from the offshore transport of pollutants during the night by the land breeze and their chemical transformations and readvection toward the city by the sea breeze during the following morning and afternoon. Because the nocturnal flow carries pollutants along the peninsula coast, nocturnal emissions also have an effect on ozone concentrations at the southern edge of the peninsula.

The effect of mutual interaction $\left(\hat{S}_{D N}=S_{\text {tot }}-S_{D}-\right.$ $S_{N}+S_{0}$ ) between daytime and nighttime emissions (Fig. $7 \mathrm{c})$ is negative almost everywhere, reaching values as low as $-40 \mathrm{ppb}$ at Parnitha. This result implies that combining daytime and nighttime emissions can lead to a reduction of ozone concentrations. Note that the mutual effect area is relatively broad and is located mainly inland.

An explanation for the behavior of $\hat{S}_{D N}$ (negative for $\mathrm{O}_{3}$, positive for $\mathrm{NO}_{\mathrm{x}}$ ) is the following: an increase of both VOC and $\mathrm{NO}_{\mathrm{x}}$ compounds leads to a reduction of hydroxyl $(\mathrm{OH})$ radical concentration, and $\mathrm{O}_{3}$ production becomes less efficient. This $\mathrm{O}_{3}$ production becomes proportionally lower for high primary pollutant-concentration conditions, that is, primary pollutants (PP) transform less and less efficiently, and the $\mathrm{O}_{3}$ :PP ratio decreases (Sillman et al. 1990; Liu et al. 1987).

Let us now compare the pollutant concentrations reached with both emission types $\left(S_{\text {tot }}\right)$ with those resulting only from the transformation of the previous day's remaining background $\left(S_{0}\right)$. In Table 2, two specific locations within the domain are considered in more detail: Athens and Parnitha Mountain.

Because the sum of all nitrogen-containing compounds $\left(\mathrm{NO}_{\mathrm{y}}\right)$ can be considered to be a passive tracer, it behaves linearly. Indeed, the total effect $\left(S_{\text {tot }}\right)$ is exactly the sum of the nighttime $\left(\hat{S}_{N}\right)$ and daytime $\left(\hat{S}_{D}\right)$ effects and $\hat{S}_{D N}$ is zero. In general, for chemically reacting compounds the behavior is nonlinear and a nonzero mutual interaction $\hat{S}_{D N}$ is expected.

In the city of Athens, the effect of the current-day emissions $(46-3-15 \mathrm{ppb}=28 \mathrm{ppb})$ is much smaller (30\% of the maximum ozone value) than the ozone concentrations reached in the $S_{0}$ simulation, through transport and transformation of previous-day (background) emissions (67 ppb, or about $70 \%$ ). Moreover, from Table 2, it is evident that the effect of nighttime emissions is very important (46 ppb; about $48 \%$ of total ozone), and daytime emissions are almost ineffective. Then, the only way to reduce ozone pollution in this area seems to be by lowering night emissions. On the other hand, a slight positive mutual interaction is seen for $\mathrm{NO}_{\mathrm{x}}$ concentrations.

At Parnitha Mountain, each emission type (day and night) has a strong effect on ozone concentrations ( 55-60 ppb), but the interaction between the two is nearly as large $(\sim 35 \mathrm{ppb})$. This result indicates that reducing ozone concentrations there implies the need to consider nighttime and daytime emissions together before deciding on an abatement strategy. On the other hand, the sum of the current-day effects $(60+55-$ $35=80 \mathrm{ppb}$, that is, about $60 \%$ of the total ozone peak) is larger than the transformation arising from the previous-day residual (53 ppb; about $40 \%$ ), which indicates that, at this location, ozone concentrations are controlled more by the current day's emissions than by background concentrations.

A more general view of the area is shown in Fig. 7d, which maps the effect of emissions on ozone peak concentrations in comparison with concentrations reached from photochemical transformation of background values $\left(S_{\text {tot }}-S_{0}\right)$. The figure indicates again that the moun- 
(a)

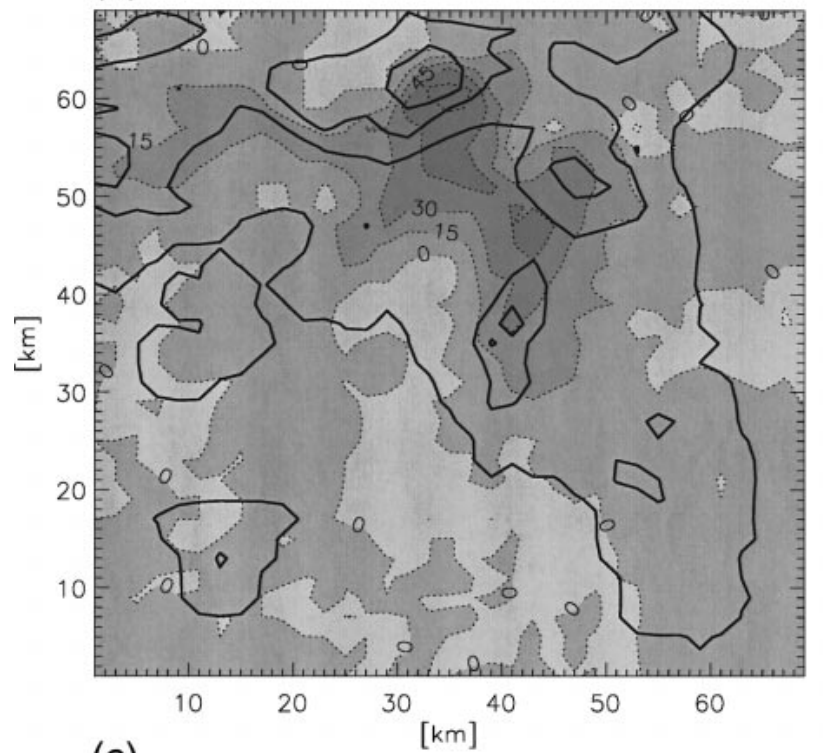

(c)

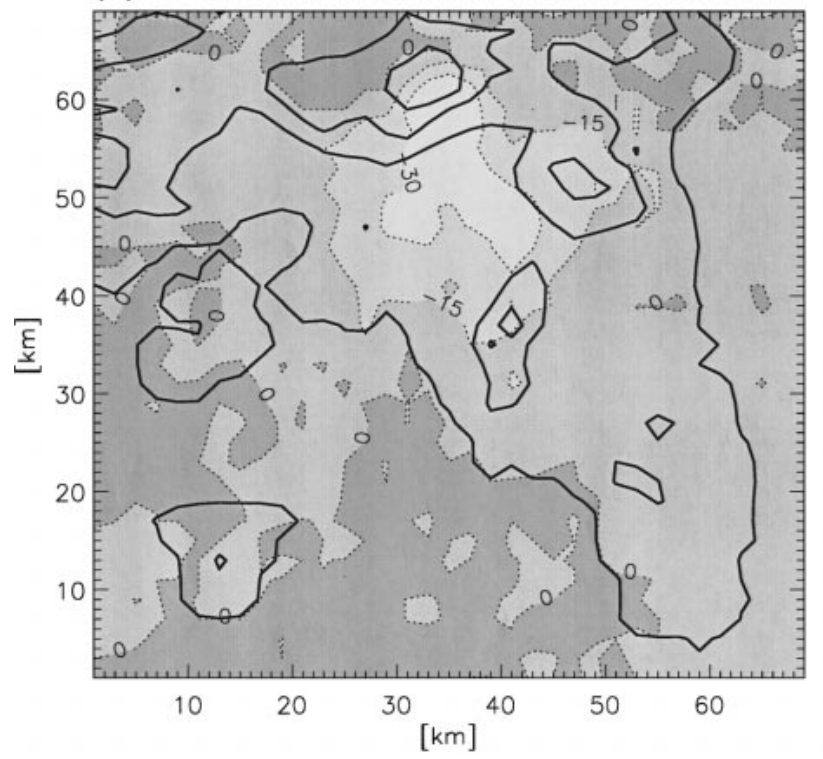

(b)

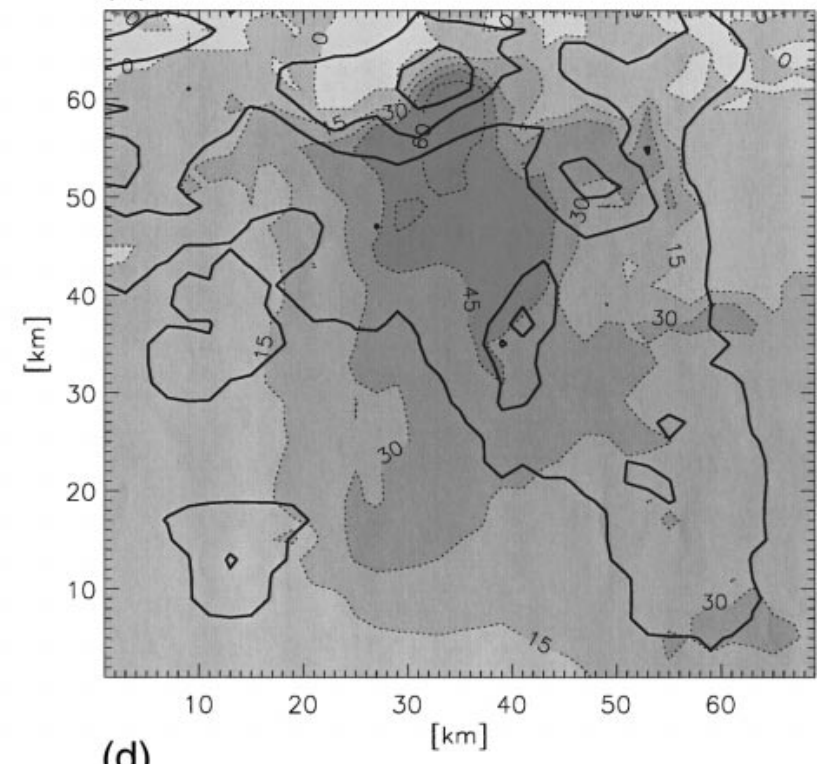

(d)

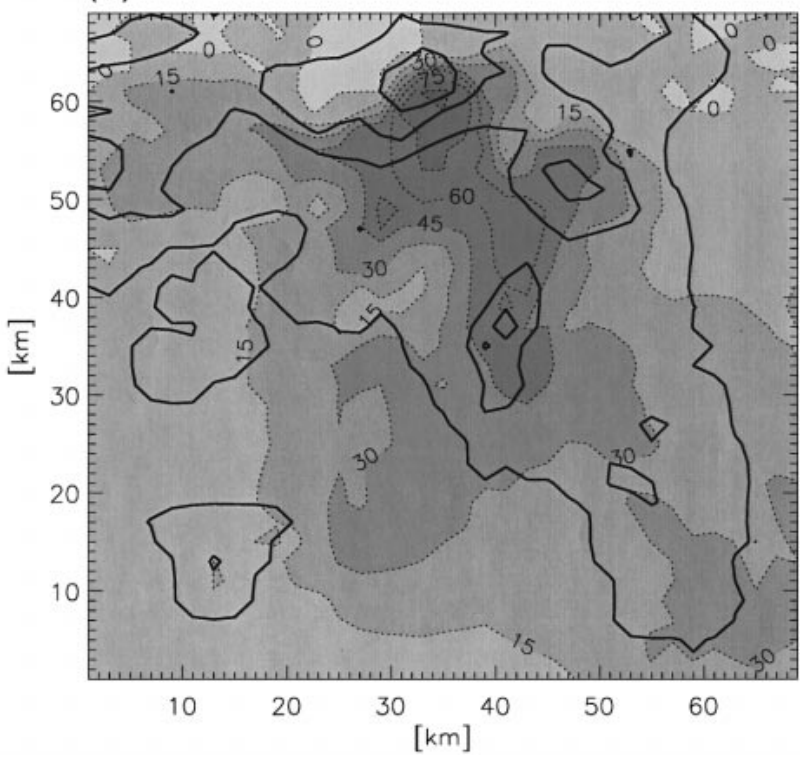

FIG. 7. Map of 15-m ozone values reached at the time of maximum of the control simulation $\left(S_{\text {tot }}\right)$. (a) Effect of daytime emissions $\left(\hat{S}_{D}\right)$, (b) effect of nighttime emissions $\left(\hat{S}_{N}\right)$, (c) effect of mutual interaction $\left(\hat{S}_{D N}\right)$, and (d) effect of current-day emissions $\left(S_{\text {tot }}-S_{0}\right)$.

TABLE 2. Detail of the contributions to ozone pollution concentrations reached at two specific locations within the Athens basin.

\begin{tabular}{cccrcc}
\hline \hline & $\begin{array}{c}S_{\text {tot }}= \\
(\mathrm{ppb})\end{array}$ & $\begin{array}{c}S_{0} \\
(\mathrm{ppb})\end{array}$ & $\begin{array}{c}+\hat{S}_{N} \\
(\mathrm{ppb})\end{array}$ & $\begin{array}{c}+\hat{S}_{D} \\
(\mathrm{ppb})\end{array}$ & $\begin{array}{c}+\hat{S}_{D N} \\
(\mathrm{ppb})\end{array}$ \\
\hline Athens & & & & & \\
$\mathrm{NO}_{\mathrm{y}}$ & 68 & 3 & 12 & 53 & 0 \\
$\mathrm{NO}_{\mathrm{x}}$ & 52 & 0 & 3 & 48 & 1 \\
$\mathrm{O}_{3}$ & 95 & 67 & 46 & -3 & -15 \\
Parnitha & & & & & \\
$\mathrm{NO}_{\mathrm{y}}$ & 60 & 1 & 12 & 47 & 0 \\
$\mathrm{NO}_{\mathrm{x}}$ & 33 & 0 & 2 & 29 & 2 \\
$\mathrm{O}_{3}$ & 133 & 53 & 60 & 55 & -35 \\
\hline
\end{tabular}

tain region surrounding Athens is the most affected by current-day emissions, and the Athens downtown region shows almost no effect.

A cross section along a line passing through the center of Athens and through Parnitha is used to illustrate how the effect of different emissions is structured in a vertical plane. For $S_{\text {tot }}$ (Fig. 8a), values of about 100 ppb are seen over the Athens basin, with larger concentrations offshore, whereas the highest concentrations (150 ppb) are located within the return current between 300 and $500 \mathrm{~m}$.

The influence of daytime emissions (Fig. 8b) is almost negligible in the first $200 \mathrm{~m}$ above the surface (both 
(a)

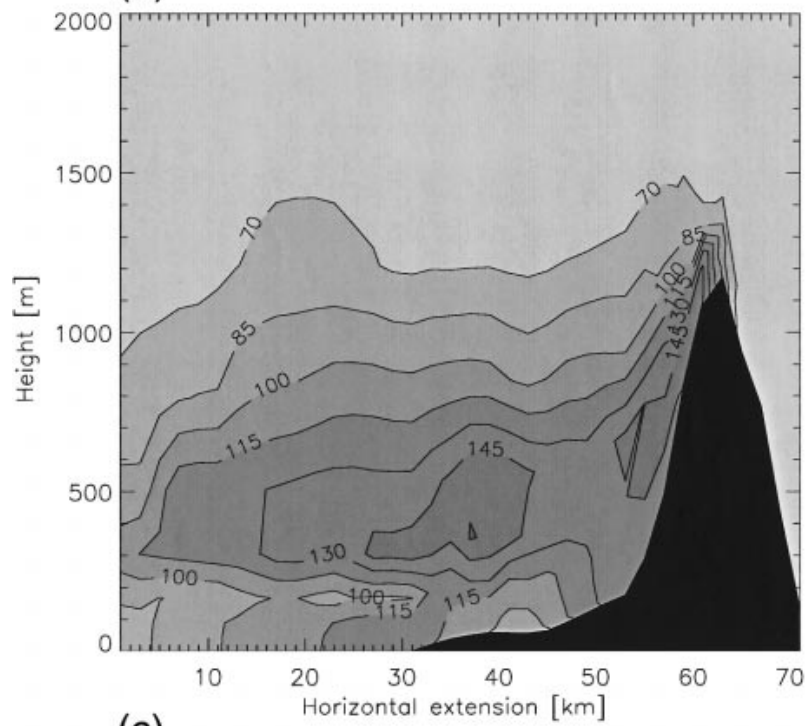

(c)

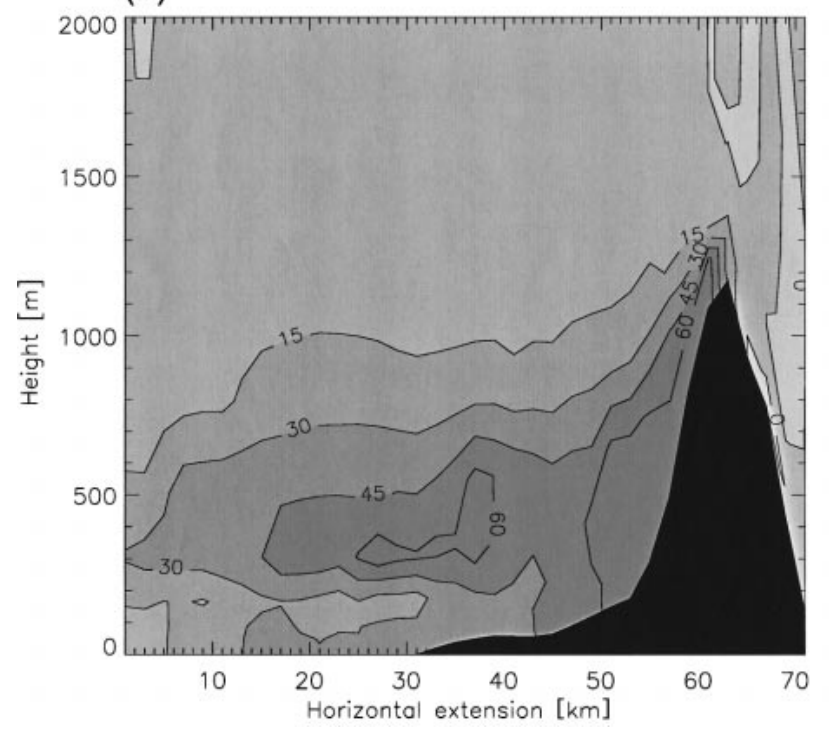

(b)

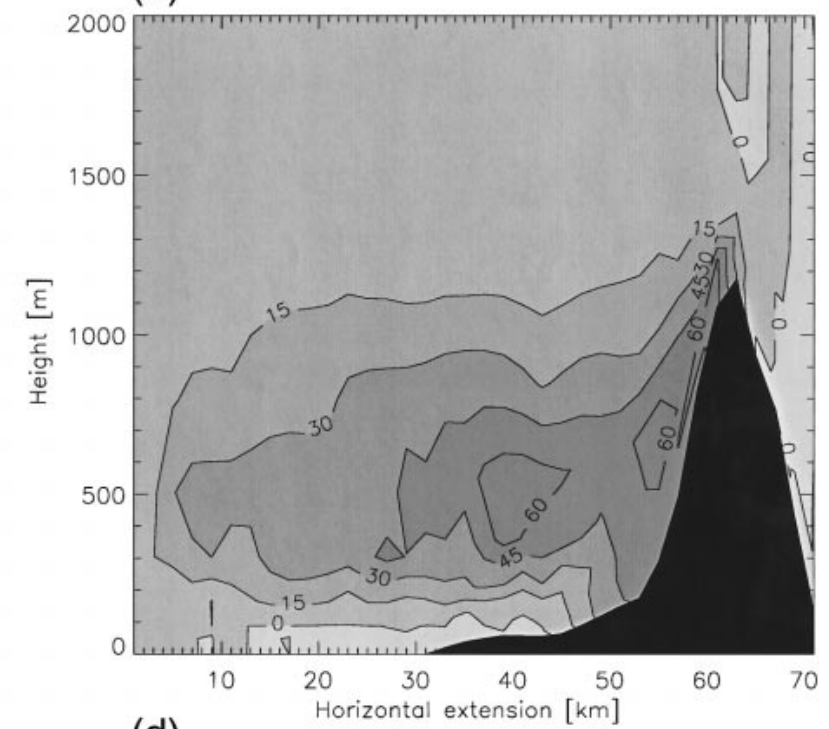

(d)

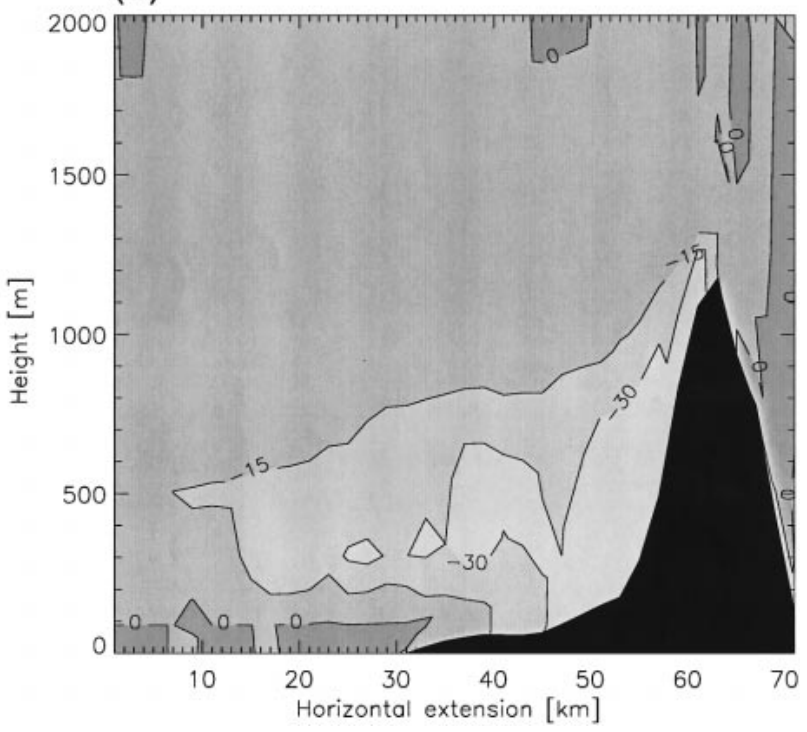

FIG. 8. Vertical north-south cross section of ozone values at the time of maximum in the control simulation $\left(S_{\text {tot }}\right)$. (a) Control simulation $\left(S_{\text {tot }}\right)$, (b) effect of daytime emissions $\left(\hat{S}_{D}\right)$, (c) effect of nighttime emissions $\left(\hat{S}_{N}\right)$, and (d) effect of mutual interaction $\left(\hat{S}_{D N}\right)$.

inland and over the sea), but in the return current (from 200 to $1000 \mathrm{~m}$ ) it becomes very important. This result is explained by the fact that daily emissions in the area between the Athens downtown and the Parnitha slopes are characterized by high $\mathrm{NO}$ emissions that slow down ozone formation. Photochemical pollutants form later and are pushed toward the mountaintop by daytime upslope flow. The largest part of these pollutants then is advected back toward the sea by the return flows, while a minor part is pushed over the mountaintop into the stable troposphere. This phenomenon, sometimes referred to as the mountain chimney effect (Lu and Turco 1994), provides a sink for surface ozone, but acts as a source of pollutants in the free atmosphere.
Note that daytime emissions strongly influence ozone surface concentrations only at stations located on mountain slopes at higher altitudes. Moreover, daytime emissions can affect ozone concentrations the following day through the return current and next-day sea breeze (ozone episode building up). This particular point is investigated in the following section.

The effect of nighttime emissions (Fig. 8c) is important at both the surface and upper levels: the surface effect ranges from 30 to $50 \mathrm{ppb}$, and a maximum of 60 $\mathrm{ppb}$ is reached within the return current. This maximum intensity is very similar to that obtained with daytime emissions only. Because daytime emissions are much larger, the similarity between the maximum effect of 
TABLE 3. Summary table of the initialization conditions for the different scenarios considered in section $4 \mathrm{c}$. The four scenarios differ only by their initial conditions. In all four cases the 24-h simulation includes all emissions with the meteorological conditions of $14 \mathrm{Sep}$.

\begin{tabular}{lc}
\hline & Emissions during the $24-\mathrm{h}$ initialization period (14 Sep) \\
\hline$S_{\text {tot }}^{\prime}$ & Total \\
$S_{D}^{\prime}$ & Daytime only \\
$S_{N}^{\prime}$ & Nighttime only \\
$S_{0}^{\prime}$ & None \\
\hline
\end{tabular}

day and night emissions over the domain indicates a higher efficiency of the latter in producing ozone over the Athens basin. This higher efficiency could be due to a longer residence time of night emissions in the atmosphere or to the trapping of nighttime emissions in a shallow layer during the morning hours over the sea.

The mutual interaction map (Fig. 8d) shows almost no effect near the surface and a negative maximum influence located between 300 and $400 \mathrm{~m}$ above the city of Athens. This result confirms what was observed on the horizontal cross sections, that is, that night and day emissions mostly are decoupled near the surface and the opposite is true aloft or along Parnitha Mountain slopes. The contribution of the current-day (14 September) emissions, that is, the day plus night effect $\left(S_{\text {tot }}-S_{0}\right)$, on the observed maximum is on the order of $25 \mathrm{ppb}$ out of $120 \mathrm{ppb}$, or about $20 \%$, near the surface, whereas within the reservoir layer it reaches $80 \mathrm{ppb}$ out of 150 ppb $(>50 \%)$, the remaining part resulting from photochemical reactions of background species.

\section{c. Role of pollutant recirculation}

As discussed above, the coupled sea-breeze and mountain-slope circulation generates increased photochemical pollutant concentrations within the return flow (300-1000 m above ground). To define ozone abatement strategies, it is essential to understand whether these pollutants, which are formed during one sea-breeze-regime day, could be retransported over the Athens basin during the following days. To this end, the meteorological conditions (sea breeze) of 14 September are assumed to repeat identically the next day.

For this specific day, four simulations are performed with the complete emission inventory but with different initial conditions for chemistry (Table 3). These initial conditions correspond to the resulting concentration fields obtained at the end of the simulations presented in the previous section $\left(S_{\text {tot }}, S_{d}, S_{n}\right.$, and $\left.S_{0}\right)$.

The horizontal cross section of the control run $\left(S_{\mathrm{tot}}^{\prime}\right)$ results is shown in Fig. 9a. The buildup of pollutant amounts during two consecutive sea-breeze days can be analyzed from $\hat{S}_{D}^{\prime}\left(S_{D}^{\prime}-S_{0}^{\prime}\right)$. Figure $9 \mathrm{~b}$ shows the difference between a run initialized with daytime emissions only $\left(S_{D}^{\prime}\right)$ and one initialized without emissions $\left(S_{0}^{\prime}\right)$; it therefore indicates the effect of the previous daytime emissions on the current-day ozone peak concentrations.
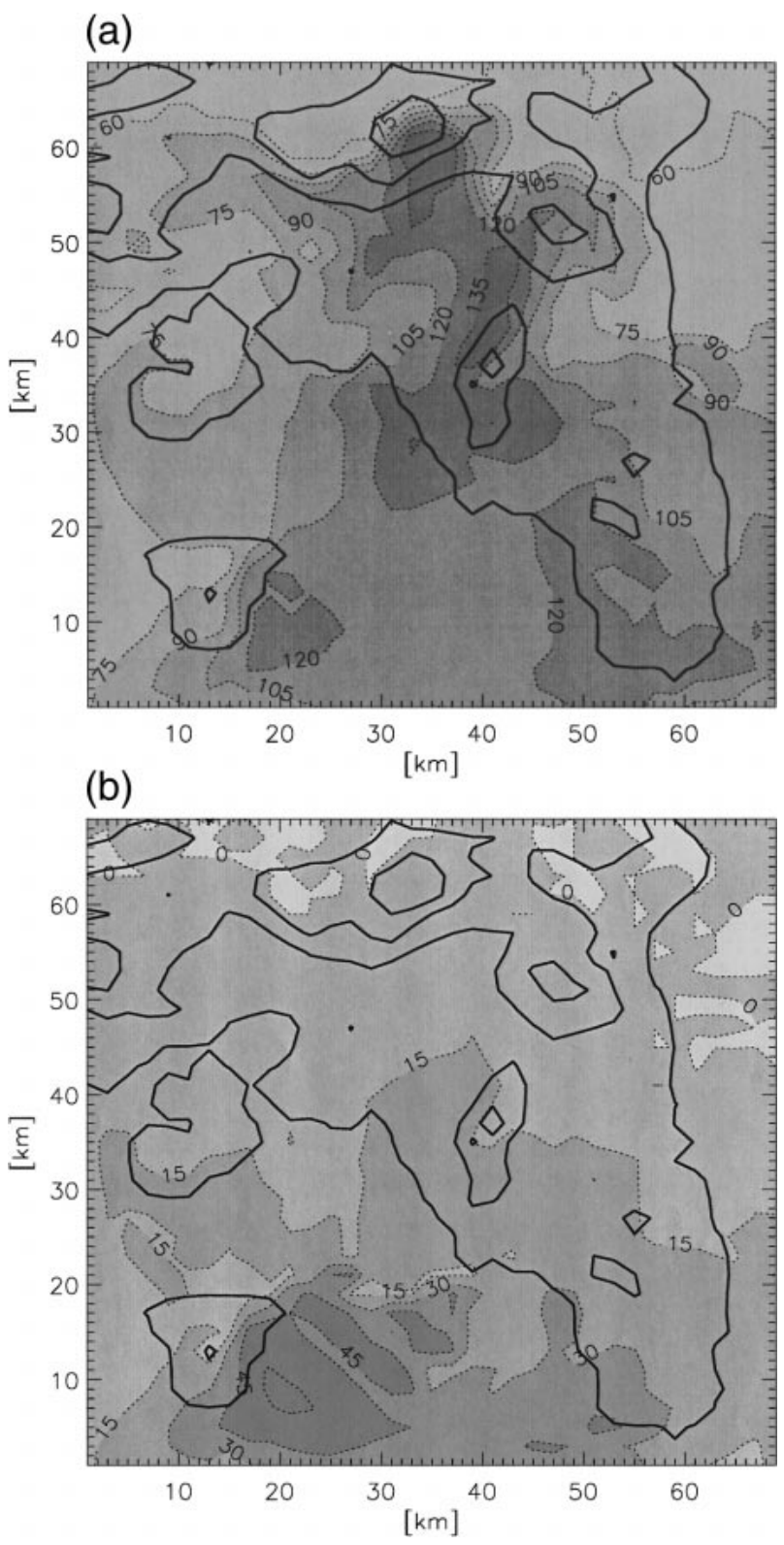

FIG. 9. Map of 15-m ozone values reached at the time of maximum of the control simulation $\left(S_{\text {tot }}^{\prime}\right)$. (a) Control simulation $\left(S_{\text {tot }}^{\prime}\right)$ and (b) effect of 14 Sep daytime emissions on the second-day concentrations $\left(S_{D}^{\prime}\right)$

This map shows that daytime emissions from the previous day only have an effect over sea, especially near Aigina Island. In particular, the effect on the Athens basin is very small. The effect of previous-night emissions on ozone concentrations $\left(\hat{S}_{N}^{\prime}\right)$ is negligible everywhere and the same is true for the mutual interaction $\left(\hat{S}_{D N}^{\prime}\right)$. The only effect of previous-day emissions occurs over the sea and is due to daytime emissions that are carried away by the previous day's return current and are reinjected into the next day's sea breeze. This effect 
represents a contribution of approximately $50 \%$ to the ozone concentrations reached near Aigina Island.

A comparison of the two 14 September simulations with full emissions ( $S_{\text {tot }}$ and $S_{\text {tot }}^{\prime}$ ) is shown for three different stations in Fig. 10. These two simulations differ only by their initial concentration fields. The first simulation is initialized from 13 September, when the northern synoptic forcing was strong enough to prevent sea-breeze formation (no reservoir layer is generated aloft). The second is initialized from 14 September, when the sea breeze generated this ozone reservoir layer. At coastal stations in the southern part of the peninsula (Fig. 10c) a slight increase of about $20 \mathrm{ppb}$ is seen; over the Athens basin (Fig. 10b), this effect is reduced by half. On mountain slopes, ozone concentration levels remain unchanged (Fig. 10a).

\section{d. Role of the spatial distribution of emission sources}

From the emission inventory, two main sources of pollutants can be identified in GAA: the city of Athens (mainly road traffic) and the industrial area around Elefsis, in the Thriasson Plain. The Athens basin emissions represent $70 \%$ of the $\mathrm{NO}_{\mathrm{x}}$ and $60 \%$ of the VOC emitted over the area of interest during 14 September. The Elefsis basin emissions are much lower for ozone precursors, namely $13 \%$ of $\mathrm{NO}_{\mathrm{x}}$ and $17 \%$ of VOC.

A set of four simulations is necessary also in this case to quantify the individual contribution of each of these two basin emissions to the Athens basin ozone amounts as well as their mutual interaction (see Table 4).

The $s_{0}$ simulation is obtained by switching off both Athens and Elefsis basin emissions ( $s_{0}$ is different from $S_{0}$, in which all the emissions are turned off). As before, Fig. 11a shows an ozone concentration map at the time of the control simulation maximum. The highest ozone concentrations ( $\sim 85 \mathrm{ppb})$ are found along the coast in the southern part of the peninsula where emissions remain active and along the sea-breeze convergence line.

The effect of Athens emissions only $\left(\hat{s}_{A}=s_{A}-s_{0}\right)$ is illustrated in Fig. 11b. The ozone maximum is located in the mountain gap between Mt. Pendeli and Mt. Hymettus (more than $60 \mathrm{ppb}$ ) and an effect of more than $40 \mathrm{ppb}$ also is seen along the mountain slopes, in the region where the highest ozone concentrations are found in the control simulation.

The effect of Elefsis emissions only $\left(\hat{s}_{E}=s_{E}-s_{0}\right)$ is illustrated in Fig. 11c. The maximum effect on ozone concentrations ranges between 25 and $40 \mathrm{ppb}$ at the Parnitha Mountain foothill. An effect of 10-25 ppb results in the city of Athens, which is of the same order of magnitude as the contribution of the Athens basin itself. This contribution is due once again to the nighttime offshore transport of pollutants from the Elefsis basin by the land breeze and to the transport in the Athens basin during the following morning.

The maximum ozone concentrations observed at the Parnitha Mountain foothill in the control simulation $\left(s_{\text {tot }}\right)$ can be attributed to the convergence of two sea-breeze systems: one coming from Elefsis basin and one coming from Athens basin. These two systems, which both carry ozone-rich air masses, are almost equally (slightly more for the Athens basin) contributing to the maximum ozone concentrations at Parnitha. On the other hand, the increased ozone concentrations found along the slopes of Mt. Pendeli and Mt. Hymettus primarily are due to Athens emissions (zero effect due to Elefsis emissions).

Figure 11d shows the difference between $s_{\text {tot }}$ and $s_{0}$, and gives an indication of the total effect of both basins on air pollution concentrations over the region. Once again, it is seen that over Athens city, current-day emissions have a relatively low effect ( $15 \mathrm{ppb})$ as compared with the no-emission case (80 ppb), but over the mountains this effect is much larger (65 ppb vs $135 \mathrm{ppb}$ ).

An interesting point arises from the analysis of the vertical cross sections (not shown). As discussed above, an ozone plume is formed aloft over sea in the $s_{\text {tot }}$ case from the effect of sea breezes and slope winds. In the $\hat{s}_{A}$ case an elevated plume of ozone is formed over the Athens basin area, but in the $\hat{s}_{E}$ case this phenomenon is not evident. This difference means that ozone concentrations found in the elevated layers over the Athens basin mainly are produced by the chemical transformation of the Athens emissions themselves.

\section{Conclusions}

The scenarios discussed in this paper have isolated and quantified the main mechanisms generating high ozone concentrations in the Athens area. The study was conducted on the 14 September photochemical smog episode. The meteorological conditions during that day were characterized by light synoptic winds that allowed local thermal circulations to develop. These conditions are frequent in Athens during the summer period. Nevertheless, other meteorological conditions could be studied using the approach employed in this paper, to get a more general understanding of the Athenian ozone problem.

From the study of daytime and nighttime emissions, it comes out that Parnitha slopes mostly are affected by daytime emissions from both Elefsis and Athens basin, and Pendeli and Hymettus slopes are affected by daytime Athens emissions only. The remaining near-surface locations (city of Athens or Thriasson Plain) mostly are influenced by nighttime emissions from the two basins.

From the analysis of the recirculation scenarios, it can be concluded that ozone production within the Athens area is primarily a 1-day phenomenon. Indeed, the high values of photochemical pollutant (up to $130 \mathrm{ppb}$ at ground) reached during summertime late afternoons are related mainly to the current-day emissions. Nevertheless, recirculation of old pollutants can have an important effect on ozone concentrations, mainly in the southern part of the peninsula and over sea (nearby Aigina Island). 
(a)

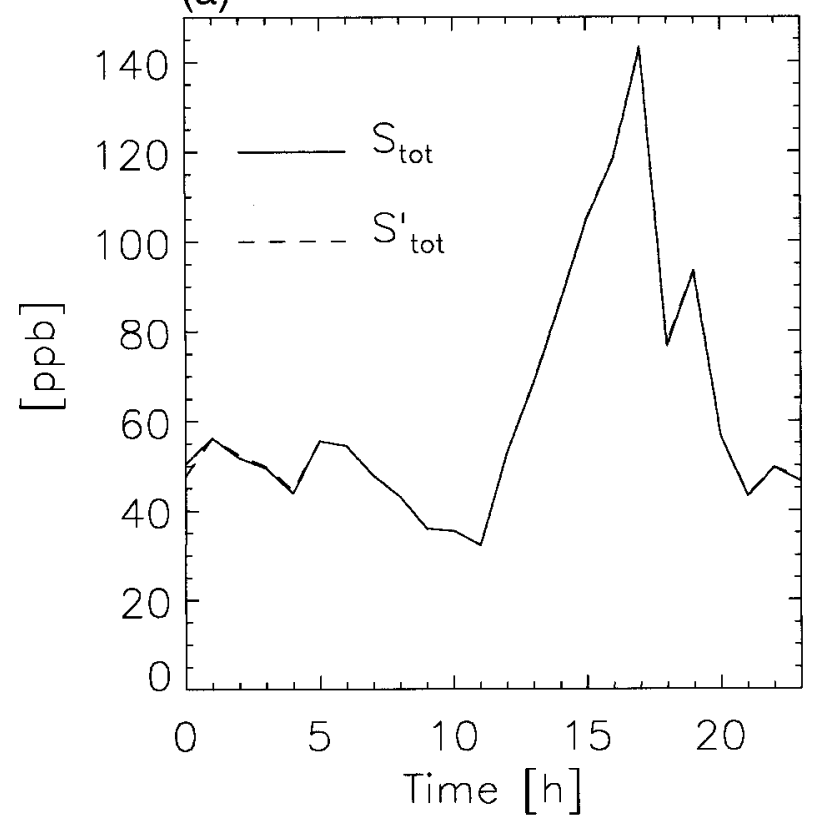

(c)

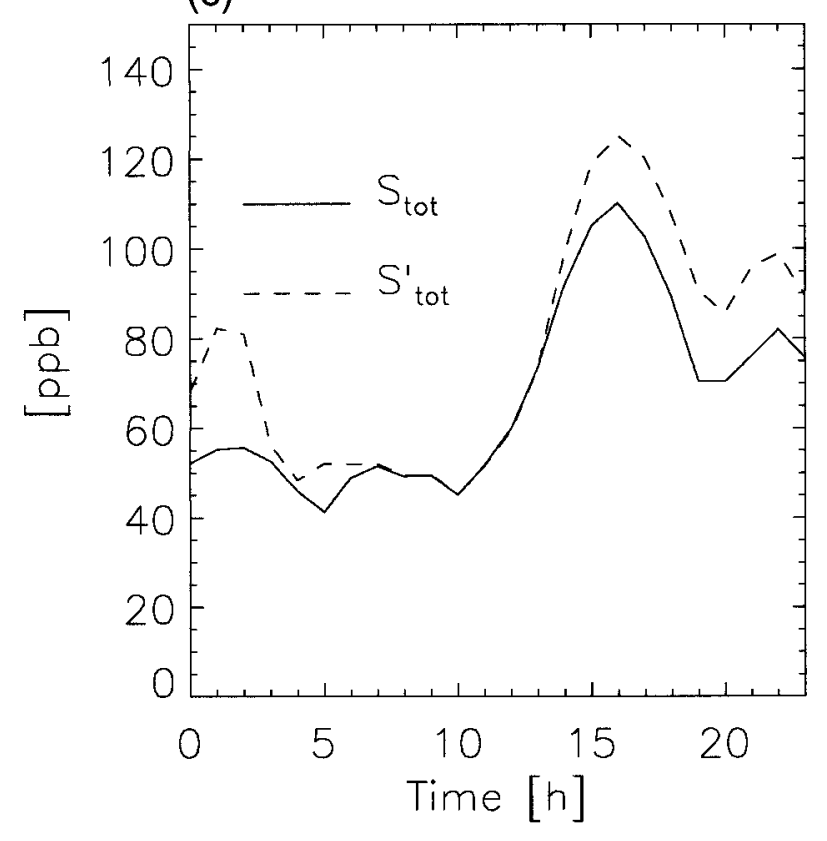

Elefsis emissions affect ozone concentrations in the Athens downtown area, and the high ozone amounts observed on the mountain slopes west of Athens mainly are due to the city emissions themselves. The ozone peak found at the Parnitha Mountain foothill is caused by the convergence of the breezes coming from Athens and Elefsis.

The actual abatement strategies mainly consist of daytime emissions reduction by limiting traffic in downtown Athens. From the result of this study, it comes out (b)

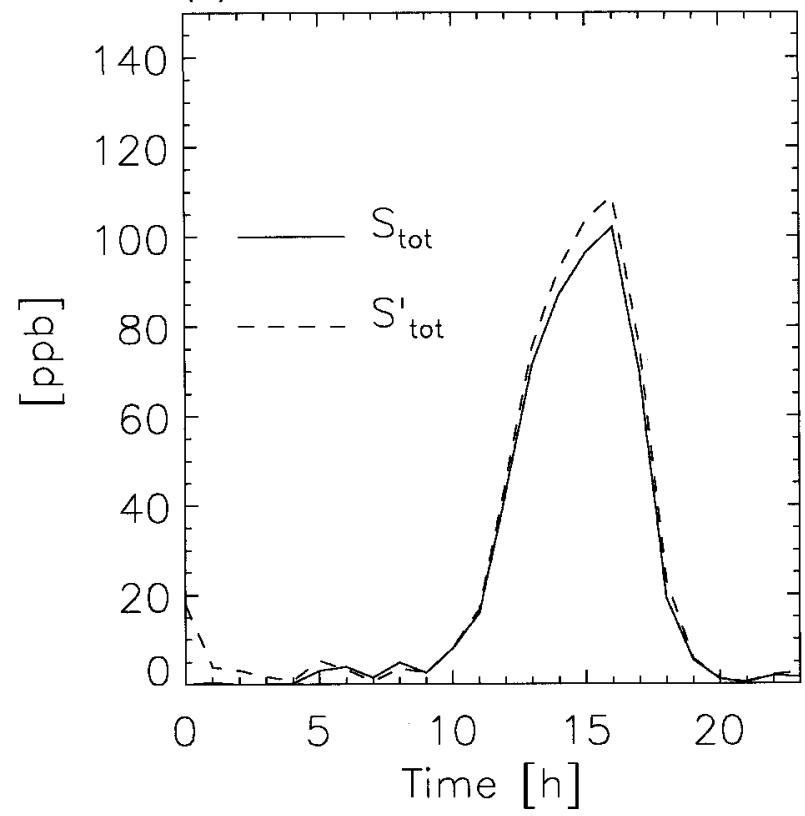

FIG. 10. Daily ozone evolution on 14 Sep and the following day at three locations: (a) Parnitha foothill, (b) downtown Athens, and (c) south of the peninsula.

that, during sea-breeze conditions, this action could lead to a drastic reduction in the ozone in the mountainous regions surrounding Athens and on the ozone accumulated in the reservoir layer, which could then recirculate during the following days. Note, however, that the reduction of ozone concentrations in the downtown area also is related to the Elefsis basin emissions and to the nighttime emissions.

A negative mutual interaction between daytime and nighttime emissions has been found in this study. This 
TABLE 4. Summary table of the simulation conditions for the different scenarios considered in section $4 \mathrm{~d}$. All simulations are initialized with the results of a 24-h simulation of 13 Sep that uses the full emission inventory. Note that $s_{\text {tot }} \neq S_{\text {tot }}$ because for $S_{\text {tot }}$ the emissions of the whole Attica peninsula are used, but for $s_{\text {tot }}$ only the Elefsis plus the Athens emissions are used.

\begin{tabular}{ll}
\hline & Emissions during the 24-h simulation period (14 Sep) \\
\hline$s_{\text {tot }}$ & Elefsis + Athens \\
$s_{E}$ & Elefsis only \\
$s_{A}$ & Athens only \\
$s_{0}$ & None \\
\hline
\end{tabular}

(a)

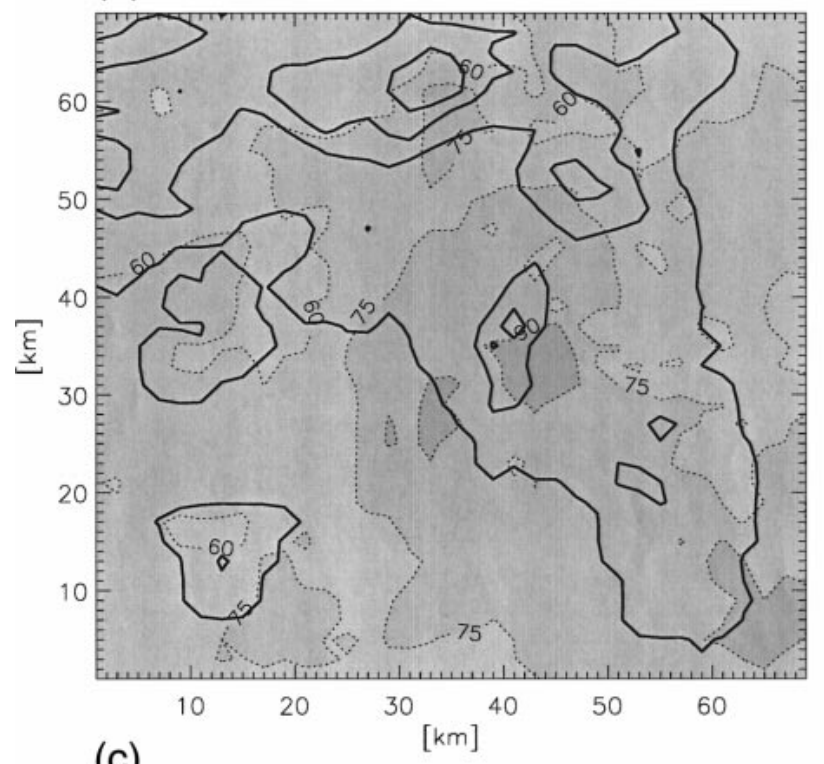

(c)

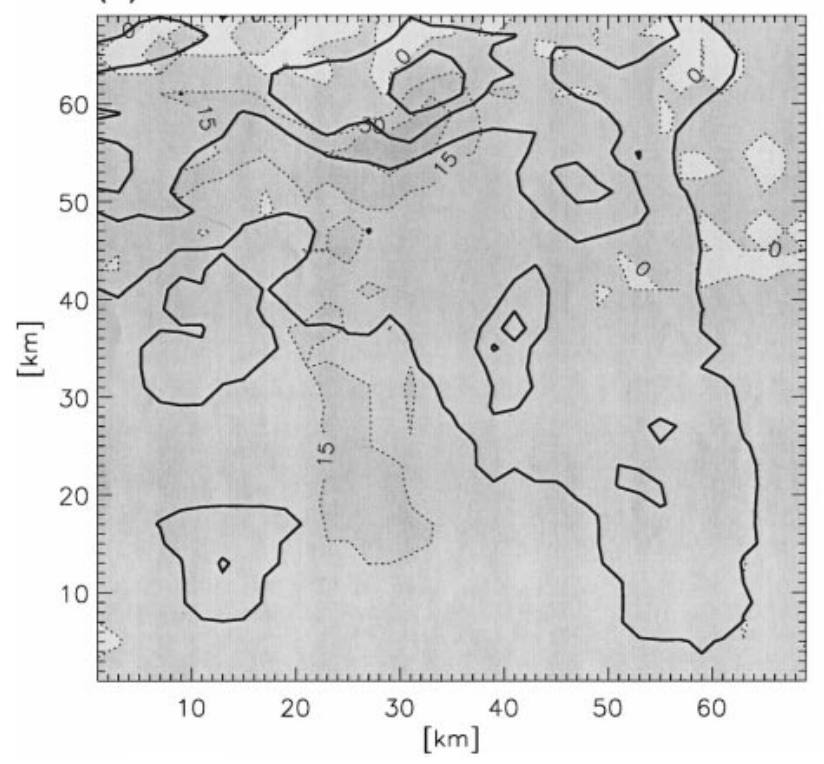

interaction implies that one cannot consider daytime emissions independently from nighttime ones when deciding on an abatement strategy to reduce ozone concentrations.

The analysis developed throughout this paper indicates the importance of better documenting experimentally the late-afternoon and nighttime periods during which the reservoir layer is developed fully and land breezes start developing, to understand the possible recirculation of air pollutants over the Athens basin. Indeed, the nighttime transport of pollutants by the land breeze was shown to be particularly important to predict
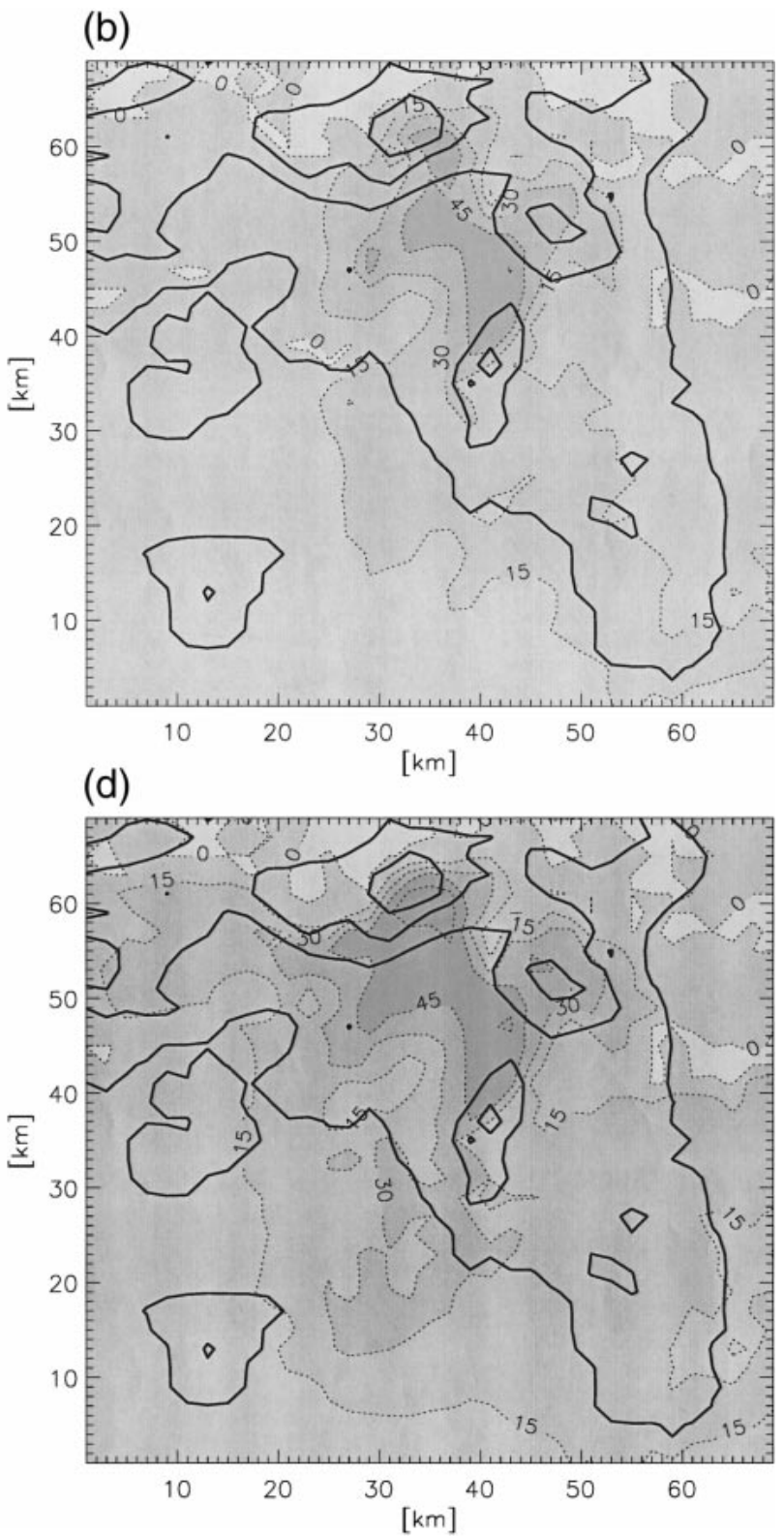

FIG. 11. Map of 15-m ozone values reached at the time of maximum of the control simulation $\left(s_{\text {tot }}\right)$. (a) Ozone concentrations generated without Athens and Elefsis basin emissions $\left(s_{0}\right)$; (b) effect of Athens basin emissions $\left(s_{A}-s_{0}\right)$; (c) effect of Elefsis basin emissions $\left(s_{E}-\right.$ $\left.s_{0}\right)$; (d) effect of Athens and Elefsis emissions $\left(s_{\text {tot }}-s_{0}\right)$. 
accurately the midday ozone maximum over Athens. Also, a higher density of measurements over the sea could help to determine the horizontal offshore extent of the sea breezes and reservoir layer, as well as nighttime pollutant amounts. In this respect, Parnitha Mountain could be an interesting location for siting a lidar station to observe the reservoir layer formation and the vertical structure of the atmosphere, because ozone maxima were simulated and observed there.

Acknowledgments. We would like to thank Drs. S. Galmarini and G. Graziani (JRC, Ispra) for many valuable suggestions.

\section{REFERENCES}

Bornstein, R. D., P. Thunis, P. Grossi, and G. Schayes, 1996: Development of the topographic vorticity-mode mesoscale- $\beta$ (TVM) model. Part II: Evaluation. J. Appl. Meteor., 35, 18241834.

Clappier, A., and Coauthors, 2000: Effect of sea breeze on air pollution in the greater Athens area. Part I: Numerical simulations and field observations. J. Appl. Meteor., 39, 546-562.

Gusten, H., G. Heinrich, T. Cvitas, L. Klasinc, B. Ruscic, D. Lalas, and M. Petrakis, 1988: Photochemical formation and transport of ozone in Athens, Greece. Atmos. Environ., 22, 1855-1861.

Harley, R. A., A. G. Russell, G. J. McRae, G. R. Cass, and J. H. Seinfeld, 1993: Photochemical modeling of the Southern California Air Quality Study. Environ. Sci. Technol., 27, 378-388.

Kallos, G., P. Kassomenos, and R. Pielke, 1991: Synoptic and mesoscale weather conditions during air pollution episodes in Athens, Greece. Bound.-Layer Meteor., 62, 163-184.

Liu, S. C., M. Trainer, F. C. Fehsenfeld, D. D. Parrish, E. J. Williams,
D. W. Fahey, G. Hubler, and P. C. Murphy, 1987: Ozone production in the rural troposphere and the implications for regional and global ozone distributions. J. Geophys. Res., 92, 4191-4207.

Lu, R., and R. P. Turco, 1994: Air pollutant transport in a coastal environment. Part I: Two-dimensional simulations of sea-breeze and mountain effects. J. Atmos. Sci., 51, 2285-2308.

Lurmann, F. W., W. P. Carter, and L. A. Coyner, 1987: A surrogate species chemical reaction mechanism for urban-scale air quality simulation models. Part I: Adaptation of the mechanism. EPA Rep. 600/387/014A, 211 pp. [Available from National Technical Information Service, 5285 Port Royal Road, Springfield, VA 22161.]

McRae, W., R. Goodin, and J. H. Seinfeld, 1982: Development of a second-generation mathematical model for urban air pollution. Part I: Model formulation. Atmos. Environ., 16, 679-696.

Moussiopoulos, N., P. Sahm, and C. H. Kessler, 1995: Numerical simulation of photochemical smog formation in Athens, Greece-A case study. Atmos. Environ., 29, 3619-3632.

Nester, K., 1995: Influence of sea breeze flows on air pollution over Attica Peninsula. Atmos. Environ., 29, 3655-3670.

Pilinis, C., P. Kassomenos, and G. Kallos, 1993: Modelling of photochemical pollution in Athens, Greece. Application of the RAMS-CALGRID modelling system. Atmos. Environ., 27B, 353-370.

Schayes, G., P. Thunis, and R. D. Bornstein, 1996: Development of the topographic vorticity-mode mesoscale- $\beta$ (TVM) model. Part I: Formulation. J. Appl. Meteor., 35, 1815-1823.

Sillman, S., J. A. Logan, and S. C. Wofsy, 1990: The sensitivity of ozone to nitrogen oxides and hydrocarbons in regional ozone episodes. J. Geophys. Res., 95, 1837-1851.

Stein, U., and P. Alpert, 1993: Factor separation in numerical simulations. J. Atmos. Sci., 50, 2107-2115.

Thunis, P., 1995: Formulation and evaluation of a non-hydrostatic vorticity-mode mesoscale model. Ph.D. dissertation, Université Catholique de Louvain-la-Neuve, Louvain-la-Neuve, Belgium, 151 pp. [Available from Secretariat, Université Catholique de Louvain-la-Neuve, B-1348 Louvain-la-Neuve, Belgium.] 